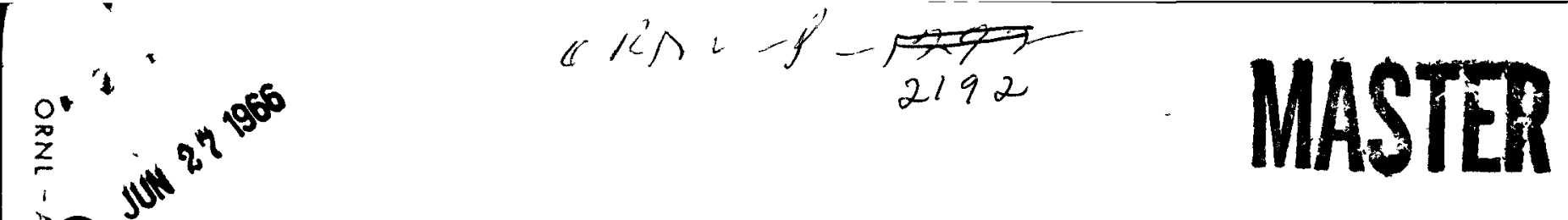

\title{
RECENT DEVELOPMENTS IN THORIUM FUEL PROCESSING*
}
E. L. Nicholson
J. W. Landry
L. M. Ferris
J. G. Moore
J. R. Flanary
R. H. Rainey
J. H. Goode
C. D. Watson
B. A. Hannaford
H. O. Witte**

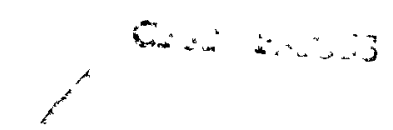

H.c. $\$ 20 ;$ inN 150

Oak Ridge National Laboratory

Oak Ridge, Tennessee

IN NUCLEAR SCIENCE ABSTRACTS

Three head-end processes are being developed for thorium-base power reactor fuels. The processes are: shear-leach for metal-clad oxides and either grind-leach or burn-leach for graphite-base High-Temperature Graphite Reactor (HTGR) fuels. The shear-leach process is being used in the first commercial fuel processing plant; further development is necessary before selecting a process for graphite-base reactor fuels.

During the past year, shear-leach studies were made on secondary problems associated with the process. These studies include calculation of the fuel temperature during the various process steps, measurement of the release of krypton and tritium during processing, the zirconium-metal fines safety problem, development of an instrument for monitoring hulls for leaching losses, and shearing tests on second-generation fuel elements.

\footnotetext{
* Research sponsored by the U.S. Atomic Energy Commission under contract with the Union Carbide Corporation.
}

** Guest scientist from KFA, Juelich, Germany.

\section{LEGAL NOTICE}

This report was prepared as an account of Government sponsored work. Neither the United States, nor the Commission, nor any person acting on behalf of the Commission:

A. Makes any warranty or representation, expressed or implied, with respect to the accuracy, completeness, or usefulness of the information contalned in this report, or that the use of any information, apparatus, method, or process disclosed in this roport may not infringe privately owned rights; or

B. Assumes any llabilities with respect to the use of, or for damages resulting from the

use of any Information, apparatus, method, or process disciosed in this report.
As used in the above, "person acting on behalf of the Commission" Includes any employee or contractor of the Commission, or employee of such contractor, to the extent that such employee or contractor of the Commission, or employee of such contractor prepares, disseminates, or provides access to, any information pursuant to his employment or contract with the Commission, or his employment with such contractor. 


\section{DISCLAIMER}

This report was prepared as an account of work sponsored by an agency of the United States Government. Neither the United States Government nor any agency Thereof, nor any of their employees, makes any warranty, express or implied, or assumes any legal liability or responsibility for the accuracy, completeness, or usefulness of any information, apparatus, product, or process disclosed, or represents that its use would not infringe privately owned rights. Reference herein to any specific commercial product, process, or service by trade name, trademark, manufacturer, or otherwise does not necessarily constitute or imply its endorsement, recommendation, or favoring by the United States Government or any agency thereof. The views and opinions of authors expressed herein do not necessarily state or reflect those of the United States Government or any agency thereof. 


\section{DISCLAIMER}

Portions of this document may be illegible in electronic image products. Images are produced from the best available original document. 
Grind-leach process studies were done in the laboratory and in small-engineeringscale experiments with unirradiated HTGR fuel. Grinding, leaching, and washing conditions have been determined for satisfactory recovery of the uranium and thorium. Engineering problems associated with grinding graphite and filtering graphite slurries are also being studied.

For the burn-leach process, estimates were made of the fission-product activity in the off-gas from a fluidized-bed burner. Fission product behavior and other problems associated with burn-leach processing are being studied in hot-cell experiments.

Other studies include protactinium recovery by adsorption on unfired Vycor glass, and chemical and engineering studies of a close-coupled processing plant in which simplified, low-cost, limited-decontamination processing methods are used to prepare feed materials for an associated fuel-fabrication plant operated by remote control.

\section{INTRODUCTION}

The recent development work at Oak Ridge National Laboratory (ORNL) on thorium fuel processing has been primarily concerned with head-end processes and with conceptual studies of close-coupled processing and fabrication plants. The purpose of this report is to summarize the information developed in the past year.

For the metal-clad $(U-T h) O_{2}$ fuels, a shear-leach process is the preferred headend process and is very nearly fully developed for industrial application. We are now doing work on secondary problems that deal with operating safety and convenience and problems associated with newer fuel types. The Nuclear Fuel Services (NFS) shear-leach 
operating experience will be available soon; therefore, our program will be deemphasized in the near future.

For the graphite-base High-Temperature Gas-Cooled Reactor (HTGR) fuels, we are developing both a bum-leach process and a grind-leach process. Each process is feasible but has several major problems that require solution before the processes can be considered for plant-scale use. The principal problem in the burn-leach process is cleanup of the burner off-gas. Cleanup is required to remove fission products that are volatilized at elevated temperatures in the burner and to remove entrained particulate material. For the grind-leach process, the problems are storage of highly active graphite waste and the extra head-end steps to remove soluble organic compounds before solvent extraction. At present, we prefer the burn-leach process and are developing the grindleach process primarily as a backup for fuels having refractory coatings, such as $\mathrm{SiC}$ and $\mathrm{Al}_{2} \mathrm{O}_{3}$, on the fuel particles. Obviously, the head-end process selection for HTGR fuels may be strongly influenced by factors such as plant capacity, or by major changes in fuel design. For example, will the fuel particles be easily separated from the structural graphite? What scheme will be used to separate bred $233 U$ from the $235 U$ particle which contains $236 U$ after irradiation? Since the HTGR concept is several years away from large-scale, multireactor exploitation, it is premature to make a choice between the two head-end processes.

Solvent extraction, using the Acid Thorex process, ${ }^{1}$ is considered the best method of recovering uranium and thorium. No development work has been done recently on the Acid Thorex process, although some work will be done in the near future as part of our close-coupled process studies. 
The results of the initial phase close-coupled process program indicate that continuous solvent extraction is the best processing choice, even for low-decontamination processing. Preliminary cost information indicates that processing in a small, closecoupled plant may cost no more than the published costs for processing the Indian Point $\mathrm{ThO}_{2}$ core in the Nuclear Fuel Services plant. This is an encouraging comparison for such a small plant. However, thorium processing and remote fabrication are still more expensive $(\geq 30 \%)$ than the low-enrichment uranium fuel cycle for water-cooled reactors. Having demonstrated a case for close-coupled plants, we will now study advanced converters, such as the HTGR's, where the advantages of thorium fuels over low-enrichment uranium can be realized.

\section{SHEAR-LEACH PROCESSING}

The shear-leach process has been intensively investigated ${ }^{2-5}$ at ORNL and is being used by Nuclear Fuel Services to process power reactor fuels clad with stainless steel or zirconium alloys and containing cores of $\mathrm{UO}_{2}, \mathrm{ThO}_{2}-\mathrm{UO}_{2}, \mathrm{U}-\mathrm{Mo}$ alloy, or Th-U alloy.

The process consists of several basic steps (Fig. 1): fuel element disassembly, shearing the fuel into short lengths to expose the core, loading sheared fuel into baskets, leaching, monitoring the leached cladding (hulls), and waste packaging and disposal. Shear-leach has been successfully demonstrated with unirradiated prototype thoriaurania and urania-bearing fuels on an engineering scale and with irradiated fuel pin samples in hot-cell experiments. ${ }^{5}$ in the engineering-scale demonstration, ${ }^{5}$ perforated baskets containing 18 to $36 \mathrm{~kg}$ of sheared unirradiated $\mathrm{ThO}_{2}-\mathrm{UO}_{2}$ fuel were leached 
ORNL DWG 63-2800RA

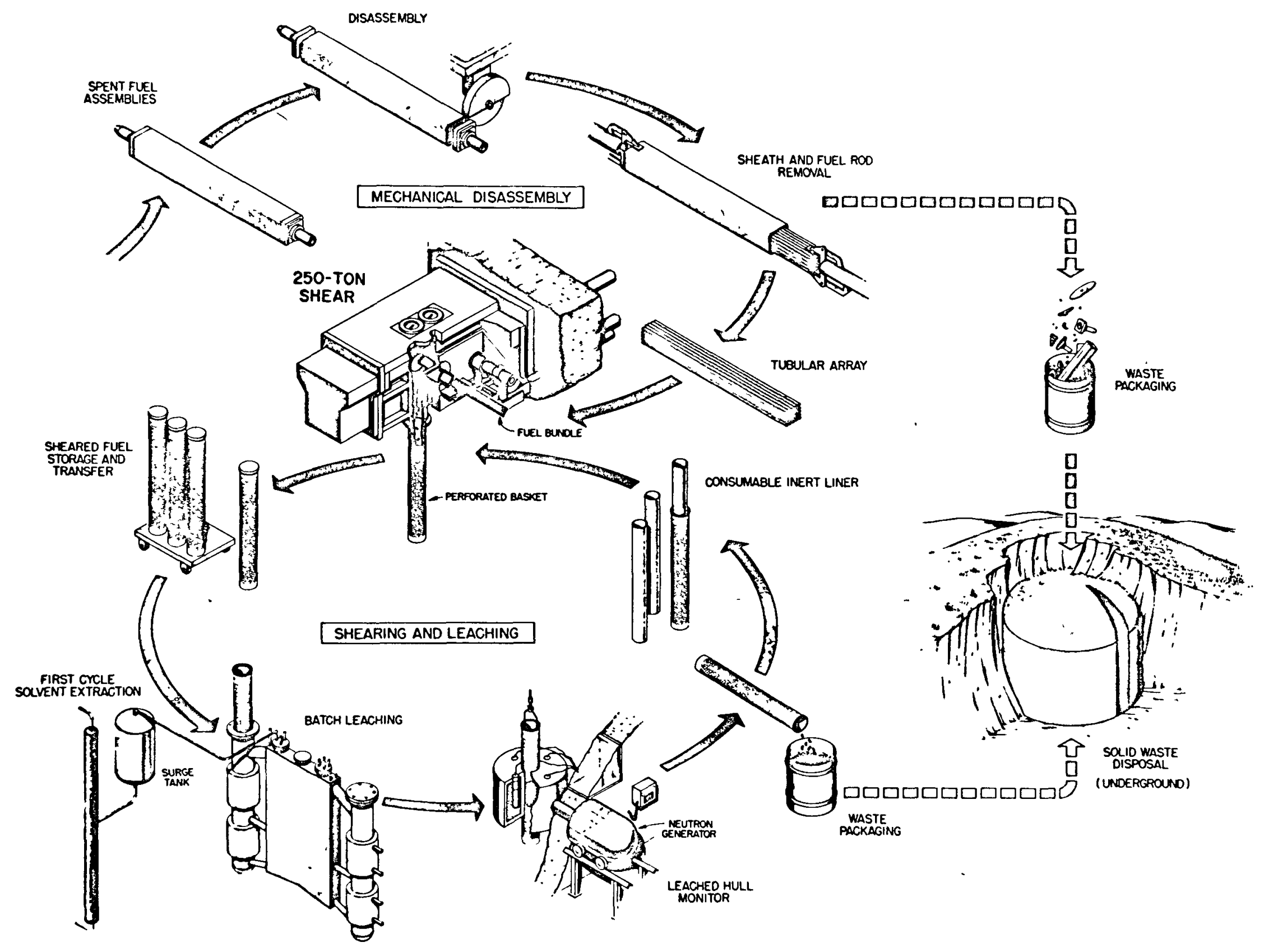

G

Fig. 1. Shear-Leach Process for Spent Reactor Fuels. 
in 8 to $26 \mathrm{hr}$ with losses of only $0.1 \%$. Unirradiated $\mathrm{UO}_{2}$ leaches in about oneeighth the time required for $\mathrm{ThO}_{2}-\mathrm{UO}_{2}$ under roughly comparable conditions, and hot-cell tests demonstrated that irradiated $\mathrm{ThO}_{2}-\mathrm{UO}_{2}$ dissolves significantly faster than unirradiated fuel. ${ }^{6}$ Other tests ${ }^{7}$ showed that from 1 to $5 \%$ of the Zircaloy cladding as well as 60 to $80 \%$ of the -10 mesh Zircaloy fines (less than $1 \%$ of the cladding weight) generated by shearing dissolves in the boiling leachant [13 $\mathrm{M} \mathrm{HNO}_{3}$ $\left.0.04 M \mathrm{HF}-0.4 \mathrm{MAl}\left(\mathrm{NO}_{3}\right)_{3}\right]$. The presence of the dissolved zirconium decreased the dissolution rate of the thoria but not enough to seriously affect the overall leaching time.

Since the primary development of the shearing and leaching process is completed, recent shear-leach development work has been on secondary items. The recent investigations are discussed in the following sections.

\subsection{Estimation of the Fuel Temperature During Shear-Leach Processing}

The internally generated heat from fission product decay may result in high fuel temperatures detrimental to the fuel or equipment during shear-leach processing. This was evaluated by computer calculations for fuel irradiated to burnups of 8,000 to 50,000 $\mathrm{Mwd} /$ metric ton at specific powers of 10 to $70 \mathrm{kw} / \mathrm{kg}$ with cooling times ranging from 180 to 1080 days. Cooling was by radiation and natural convection to the surrounding medium. In the calculations, a Yankee Atomic fuel subassembly was selected to represent a typical power reactor fuel, but the results are equally applicable to thorium oxide fuel. The subassembly consisted of a square bundle of thirty-six 0.302-in.-OD by 120 -in.-long $\mathrm{UO}_{2}$-filled stainless steel fuel rods on 0.422 -in. centers and was assumed to be irradiated to a burnup of $20,000 \mathrm{Mwd} / \mathrm{metric}$ ton at a specific power 
of $23 \mathrm{kw} / \mathrm{kg}$ and cooled 180 days. The fuel temperature was calculated for the vertical fuel subassembly in the storage canal, for the horizontal fuel element in air in the dismantling cell and in air in the shear feed envelope, and finally as sheared fuel stored in air in a 16-basket array with baskets of 5-, 7.75-, and 10-in.-ID (Table 1). The results indicate there is no danger that the fuel or clad will melt. With the possible exception of the calculated temperature of $548^{\circ} \mathrm{F}$ for the hottest fuel in the shear envelope, overheating should not be a serious problem for the shearing equipment. In any case, the temperature of the fuel in the shear envelope could be lowered considerably by forced air cooling.

\subsection{Krypton and Tritium Release During Shear-Leach Processing}

Hot-cell experiments were conducted to measure the release of krypton and tritium during shear-leach processing. ${ }^{8}$ Several stainless-steel-clad prototype Consolidated Edison fuel samples containing high-density ( $96 \%$ of theoretical) pellets of $96 \% \mathrm{ThO}_{2}-4 \%$ fully enriched $\mathrm{UO}_{2}$ irradiated to $25,000 \mathrm{Mwd} /$ metric ton were sheared in special hot-cell equipment. The first cut released $0.03 \%$ of the calculated amount of tritium and $0.5 \%$ of the ${ }^{85} \mathrm{Kr}$; multiple shearing into $1 / 2$-in. segments released a maximum of $0.26 \%$ of the tritium and $1.07 \%$ of the ${ }^{85} \mathrm{Kr}$. Tritium was released very slowly by the sheared material on standing. Only $0.26 \%$ of the tritium escaped in the dissolver off-gas when the sheared fuel was dissolved in boiling $13 \mathrm{MHNO}_{3}-0.1 \mathrm{MAl}\left(\mathrm{NO}_{3}\right)_{3}-0.05 \mathrm{MHF}$. The balance of the ${ }^{85} \mathrm{Kr}$ was released during dissolution but was not measured. Tritium oxide distillation during boildown of the dissolver solution to remove excess acid was directly proportional to the amount 
Table 1. Calculated Fuel Temperatures During Shear-Leach Processing of Stainless-Steel-Clad $\mathrm{UO}_{2}$ Fuel

\begin{tabular}{|c|c|c|c|c|}
\hline \multirow[b]{2}{*}{ Operation or Process Step } & \multicolumn{4}{|c|}{ Fuel Temperature $\left({ }^{\circ} \mathrm{F}\right)$} \\
\hline & \multicolumn{2}{|c|}{$\begin{array}{l}\text { Typical Power } \\
\text { Reactor Fuela }\end{array}$} & \multicolumn{2}{|c|}{$\begin{array}{l}\text { Highly Irradiated } \\
\text { Short-Cooled Fuel }\end{array}$} \\
\hline Canal storage & \multicolumn{2}{|c|}{71.5} & \multicolumn{2}{|c|}{75.5} \\
\hline Mechanical disassembly & \multicolumn{2}{|l|}{150} & \multicolumn{2}{|l|}{191} \\
\hline \multirow[t]{2}{*}{ Shear-feed envelope } & \multicolumn{2}{|l|}{350} & \multicolumn{2}{|l|}{548} \\
\hline & Centerline & Surface & Centerline & Surface \\
\hline \multicolumn{5}{|l|}{$\begin{array}{l}\text { Sheared fuel stored in } \\
\text { 16-basket array: }\end{array}$} \\
\hline 5-in.-ID baskets & 491 & 324 & 852 & 548 \\
\hline 7-3/4-in.-ID baskets & 720 & 453 & 1244 & 773 \\
\hline 10-in.-ID baskets & 924 & 575 & 1586 & 979 \\
\hline
\end{tabular}

a Burnup 20,000 Mwd/metric ton at $23 \mathrm{kw} / \mathrm{kg}, 180$-day-cooling.

b Burnup $50,000 \mathrm{Mwd} /$ metric ton at $70 \mathrm{kw} / \mathrm{kg}, 180$-day-cooling. 
evaporated. After rectification of the acid distillate and high-level extraction wastes, most of the tritium would eventually be discharged as a low- or intermediate-level waste stream, thus complicating low-activity-level waste disposal. Extrapolation of these data indicates that 1 curie of tritium would be released in the head-end off-gas for each metric ton of heavy metals sheared and dissolved, and hence should not be a significant off-gas problem.

Similar gas release experiments were made with prototype PWR fuel specimens containing high-density ( $93 \%$ of theoretical) $\mathrm{UO}_{2}$ pellets clad in Zircaloy-2 and irradiated to $40,000 \mathrm{Mwd} /$ metric ton. These fuel pins were also sheared into $1 / 2$-in. segments and the exposed fuel was dissolved in $4 \mathrm{MHNO}_{3}$. Shearing released $7.43 \%$ of the calculated fission yield of tritium, and only $0.13 \%$ of the total tritium was carried by the dissolution off-gas. Total release of tritium during the shearing and leaching of 1 metric ton of $\mathrm{UO}_{2}$ fuel would amount to about 37 curies, which does not appear to be a significant off-gas hazard.

The amount and composition of the undissolved residue after leaching and after the feed adjustment boildown were determined for the pins containing $\mathrm{ThO}_{2}-\mathrm{UO}_{2}$. The leaching residue amounted to $0.58 \mathrm{wt} \%$ of the original fuel and consisted principally of silica, alumina, and corrosion products with 0.74 wt $\%$ Mo, 0.23 wt $\%$ $\mathrm{Zr}-\mathrm{Nb}, 0.01$ wt $\% \mathrm{Sb}$, and insoluble uranium and thorium representing a $0.05 \%$ loss. Antimony was the principal radiation emitter. During feed-adjustment boildown, a residue precipitated that represented about $0.6 \%$ of the weight of the original fuel and contained molybdenum and zirconium plus a uranium loss of $0.02 \%$ and a thorium loss of $0.05 \%$. 


\subsection{Safety Studies on Shear-Leach Processing of Zircaloy-2-Clad Fuel}

The safety problems associated with the zirconium metal fines produced by abrasive-disk sawing and produced by shearing the fuel rods are being investigated.

Zircaloy-2 particles produced by both wet and dry abrasive cutting and containing the abrasive particles produced by disk wear in a volumetric ratio of 1 part Zircaloy-2 to 7 parts abrasive particles were subjected to spark-ignition tests in air with a 20,000-v spark. The spark tester did not ignite any of the eight size fractions which ranged from 4760 to $<44 \mu$. Electron probe analysis showed that most of the finer particles had been converted to the oxide in both the wet and dry abrasive cutting tests and were nonreactive. Thus, particles produced in a sawing operation and diluted with abrasive disk debris are considered safe to handle and store.

Shearing an 8-by-8 tube array of Zircaloy-2-clad $\mathrm{UO}_{2}$ in air produced about one to three low-energy sparks per cut and did not seem to present a fire hazard. Following shearing, the $\mathrm{UO}_{2}$ was dissolved in $6 \mathrm{MHNO}$, leaving the Zircaloy-2 fines behind. Analysis of the fines showed that, during shearing and leaching operation, the metal had not been oxidized and only a small amount, if any, of the fines had dissolved. Spark testing in air showed that Zircaloy-2 particles larger than about $150 \mu$ /in diameter did not react; however, particles smaller than this reacted with increasing violence as the particle size decreased. It is estimated that about $0.45 \mathrm{~kg}$ of Zircaloy-2 particles in the potentially hazardous size range of $<400 \mu$ is produced by shearing 1 ton of fuel. As to thoria fuel, from 60 to $80 \%$ of the -10 mesh (approximately $<1680 \mu$ ) Zircaloy particles are dissolved per pass with Thorex reagent ${ }^{5}$; 
thus, the fines do not seem to constitute a hazard for processing Zircaloy-2-clad thorium fuel. However, in shear-leach processing of Zircaloy-2-clad $\mathrm{UO}_{2}$ fuels, these potentially hazardous particles may accumulate in the equipment, since they are not readily dissolved in $6 \mathrm{MHNO}_{3}$. Here, periodic dissolution of the accumulated fines with $\mathrm{HNO}_{3}-\mathrm{HF}-\mathrm{Al}\left(\mathrm{NO}_{3}\right)_{3}$ solution, or dilution with inert solids and packaging and discarding as a solid waste, may be required.

\subsection{Leached-Hull Monitoring}

Neutron-activation analysis is being tested for monitoring the leached hulls to detect the presence of unleached fuel. ${ }^{9}$ In this method, the hulls are irradiated with neutrons from a neutron accelerator and the "delayed" neutrons are counted (Fig. 2). Both stainless steel and Zircaloy-2 hulls can be monitored and $235 \mathrm{U}, 233 \mathrm{U}$, and ${ }^{239} \mathrm{Pu}$ can be readily detected. Tests are being conducted with an 8-in.-diam by 5-ft-tall basket of hulls that contain various amounts of $235 \mathrm{U}$ (Fig. 3). The instrument will readily detect as little as $6 \mathrm{mg}$ of $235 \mathrm{U}$ in a single hull and is quite sensitive to uniformly distributed fissionable material. Uniform distribution of $100 \mathrm{mg}$ of $235 \mathrm{U}$ in the leached hulls in an 8-in. height of 8-in.-diam basket corresponds to a leaching loss of about $0.02 \%$ for a fuel containing $2 \%{ }^{235} \mathrm{U}$; thus, the instrument appears to be sensitive enough and should be quite useful for rapid monitoring of leaching losses. Development of the instrument is continuing.

\subsection{Shearing Tests on Second Generation Fuel Elements}

The spacing between fuel rods in the fuel elements of the first power reactor cores was, in general, maintained by rigid grids or by brazing the fuel tubes to each 


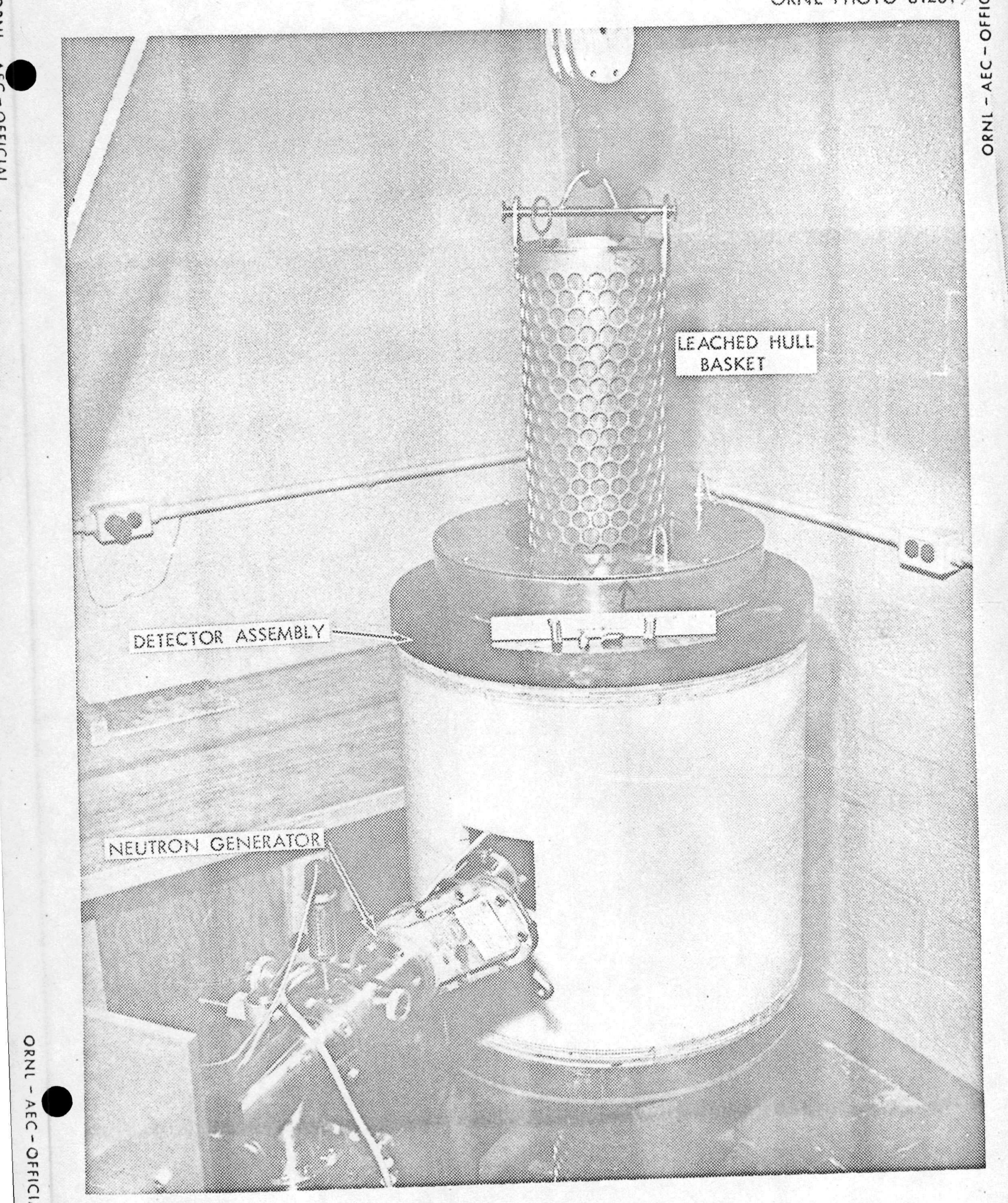

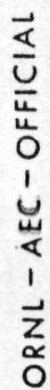

Fig. 2. Leached Hull Morikoring Instrument. 


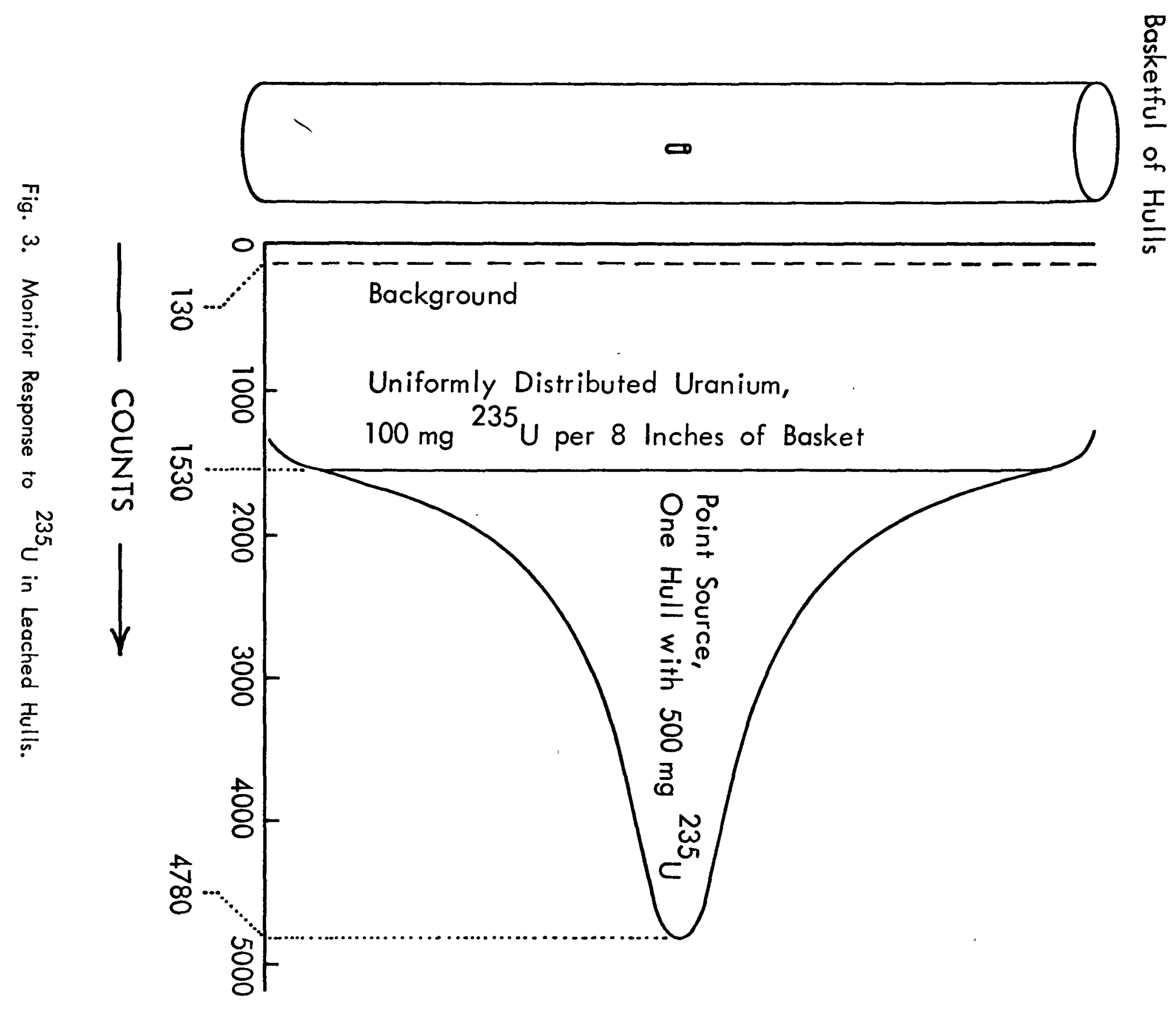

0
2
$Z$
0
0
0
0
0
1
$N$
0 
other. In the newer fuel elements, these rigid intermediate spacers have been replaced by grids in which the tubes are retained and spaced by small leaf springs or crossed wires. An example of such an assembly is the Elk River Core II $\left(\mathrm{ThO}_{2}-\mathrm{UO}_{2}\right)$ fuel assembly in which the fuel tubes are supported at intermediate points with leaf spring grid assemblies. Since the rods are less rigidly restrained than in the first cores, it was thought that shearing into uniform lengths might be more difficult. An Elk River Core II fuel assembly (porcelain-filled to simulate $\mathrm{ThO}_{2}-\mathrm{UO}_{2}$ ) was successfully sheared into 1-in. sections (Fig. 4). All terminal pieces of tubing were 2 in. long except that two pieces were $2.5 \mathrm{in}$., one was $3 \mathrm{in.,}$ and one was $4 \mathrm{in}$. long. The leaf springs remained mainly as connected metal strips. Similar results were obtained with even larger assemblies such as the Consolidated Edison Core B fuel element. With these newer fuels, it is necessary to use sharp shear blades with the clearance between fixed and moving blades not exceeding 3 to 5 mils to ensure complete cutting of the grid assemblies and of the perforated element sheath, when present. However, the grid assemblies tend to remain more or less intact and the perforated sheath yields long, flat, metal strips, complicating the shearing operation and basket loading. For this reason, an alternative shearing method, consisting in removing the tubes from the gridsheath assemblies prior to shearing and then shearing the fuel rods as a loose bundle, has been tested and is satisfactory.

\section{GRIND-LEACH PROCESS DEVELOPMENT FOR GRAPHITE-BASE HTGR FUELS}

The grind-leach process (Fig. 5) for graphite-base HTGR fuels that contain coated fuel particles consists in grinding or crushing the fuel followed by leaching the 


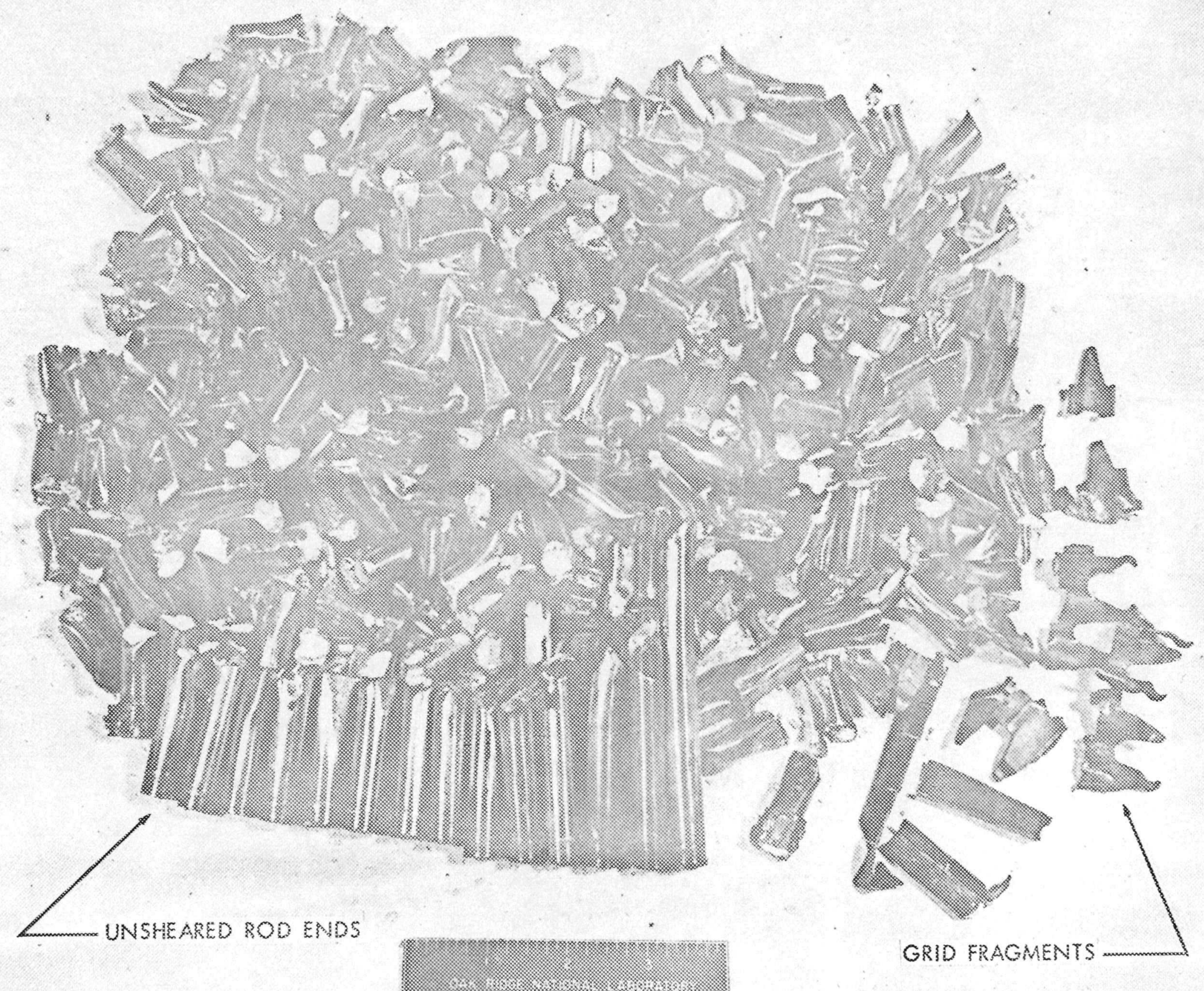


ORNL DWG. 36.684

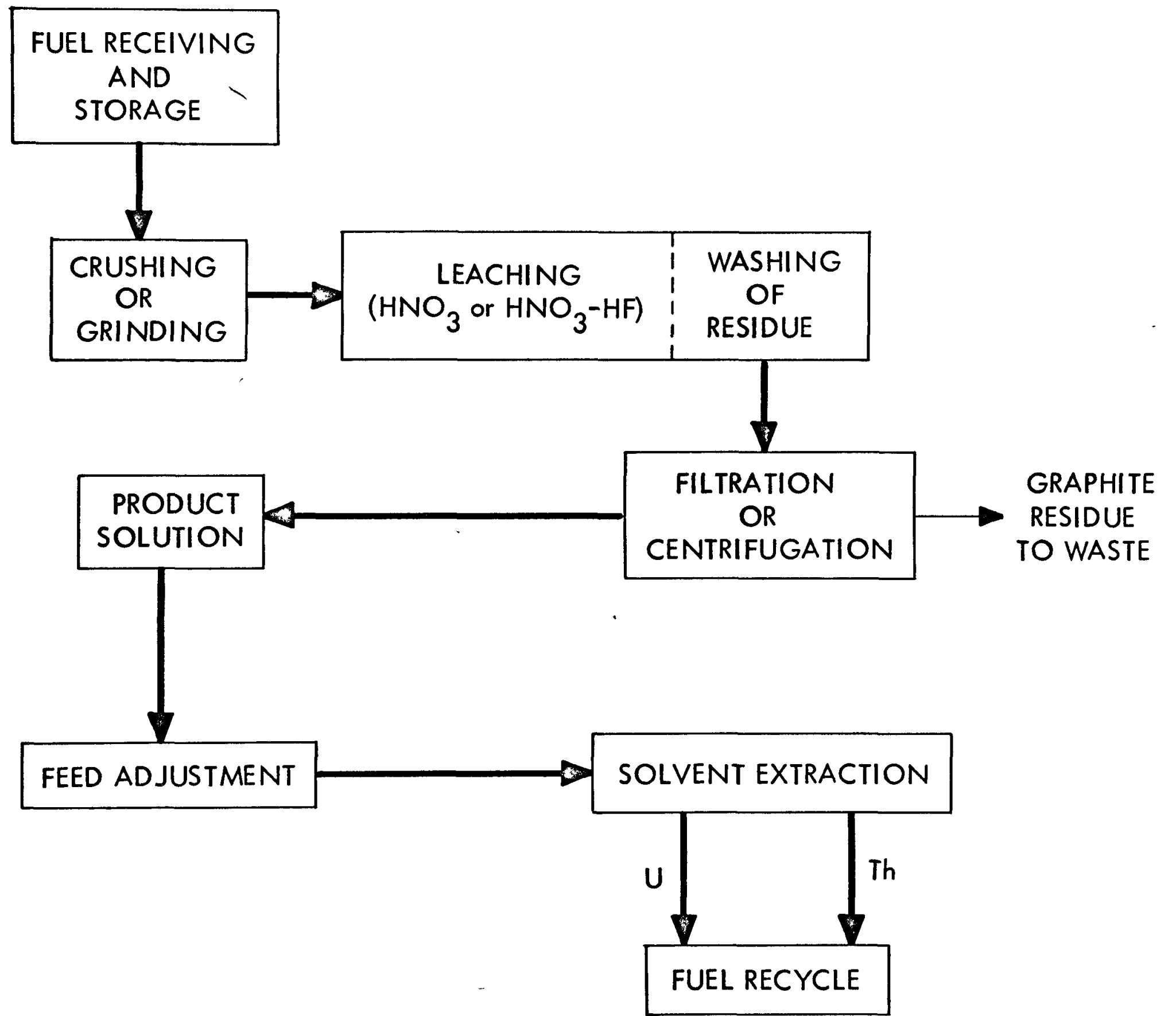

$\vec{a}$ 
powdered product with a suitable reagent. The grinding or crushing operation must effect rupture of all of the fuel particle coatings to ensure satisfactory leaching. Hence, the process is applicable to all types of coated-particle HTGR fuels, including those having refractory coatings such as $\mathrm{SiC}$ or $\mathrm{Al}_{2} \mathrm{O}_{3}$ on the particles. Ground fuels containing $\mathrm{UO}_{2}$ or uranium-thorium carbides can be leached with nitric acid alone; however, those containing $\mathrm{ThO}_{2}$ or $\mathrm{ThO}_{2}-\mathrm{UO}_{2}$ will require nitric acid with a trace of HF as the leachant. After leaching, the residual graphite is separated from the product solution and is washed to ensure maximum recovery of the uranium and thorium. The graphite residue is discarded as a waste. The disposal method will be strongly influenced by the amount of radioactivity remaining in the graphite.

The acidic solutions obtained by leaching carbide-bearing fuel may require additional chemical treatment to destroy the soluble organic compounds derived from carbide hydrolysis, if these compounds prove to be detrimental to solvent extraction performance. After pretreatment, the product solution is concentrated and the uranium and thorium are recovered by solvent extraction.

Laboratory- and small-scale engineering work was conducted with unirradiated Peach Bottom fuel compacts to study crushing, grinding, and leaching. These tests are described in the following sections. Feed preparation and solvent extraction studies on leach liquors derived from carbide-bearing fuels are in progress and hot-cell tests of the process are planned for the future.

\subsection{Size Reduction: Crushing and Grinding of HTGR Fuel}

Rough crushing of fuel compacts is desirable as a first step to prepare a smallparticle-size feed for the final fine grinding or crushing step. Unirradiated Peach 
Bottom fuel compacts were rough-crushed by a conventional hammer mill having fixed hammers on a 15-in.-diam by 8-in.-long rotor operating at $845 \mathrm{rpm}$, with the discharge bars set for 1/8-in.-wide slots. A $75 \%$ yield of -6-mesh material was obtained in a single pass. This indicates that production of a $100 \%-6$-mesh product suitable for feed to a fine grinder material should present no problem.

Early work ${ }^{10}$ on fine grinding showed that a high-speed hammer mill was excessively worn when HTGR fuels containing $\mathrm{SiC}$-coated particles were ground to 35-mesh $(500-\mu)$ particles. Ball milling was also investigated briefly ${ }^{11}$ but was unattractive because of low grinding rates, the large variation in product size, and the batchwise nature of the operation.

The roll crusher was selected as the fine-grinding method because the maximum dimension of the crushed product is determined quite accurately by the clearance between the rolls; thus, product classification equipment and recycle of oversize material can be avoided. Furthermore, the roll crusher is a very simple, continuously operated machine and should be quite satisfactory for remote use. The size reduction that can be obtained in a roll crusher is a function of the feed particle diameter, the roll diameters, the spacing between rolls (approximately equal to the product diameter), and the coefficient of friction between the feed material and the roll surfaces. This is expressed as the angle of nip, 12 and this angle is of importance for predicting the size reduction ratio per pass. With a mill having 8 -in.-diam rolls, the angle of nip was determined to be only $12^{\circ}$ for Peach Bottom fuel, primarily because of the low coefficient of friction between the fuel and the smooth steel rolls. The true angle of nip may be somewhat less than $12^{\circ}$ because this machine was not sufficiently rigid to maintain 
a preset roll spacing. Despite the problems with this machine, $80 \%$ of a -6 -mesh feed could be crushed to -140 mesh $(105 \mu)$ in three passes through the mill, decreasing the roll clearance from $0.045 \mathrm{in}$. for the first pass to $0.002 \mathrm{in}$. for the final passes. Reduction of the particle size to -140 mesh was sufficient to ensure rupture of all the fuel particle coatings. The +140 mesh fraction remained close to $20 \%$ after the second and third passes and actually increased with the fourth pass through the mill. The explanation for this anomaly is that the roll mill also compresses a great number of smaller particles (primarily from the $-140+325$ mesh range) into relatively large but very thin flakes. These flakes were up to $3000 \mu$ in diameter but were only about 50 to $140 \mu$ thick. Therefore, the effectiveness of a roll crusher in fracturing coated particles can be much greater than is indicated by a sieve analysis of the product.

Machine throughput was measured at several values of roll spacing, roll speed, and nominal feed size but the data were inconclusive. A tentative conclusion was that a roll speed of $200 \mathrm{rpm}$ gave a grinding rate for unfueled graphite of 50 to 200 $\mathrm{g} / \mathrm{min}$ for 2-in.-wide rollers. We estimate that an improved roll crusher with 8-in.-diam by 12-in.-long rolls should be able to $-16-$ mesh HTGR fuel feed to -140 mesh in a single pass at a rate of about $400 \mathrm{~kg} /$ day.

On the basis of information obtained with the 8-in.-diam roll crusher, an improved machine was designed and built at ORNL (Fig. 6). The 12-in.-diam rolls of this machine are designed to produce -140 -mesh product in a single pass, from -12-mesh material. Two aspects of the design and fabrication received special attention: The roll spacing mechanism was improved to make it very rigid, and a very small clearance 


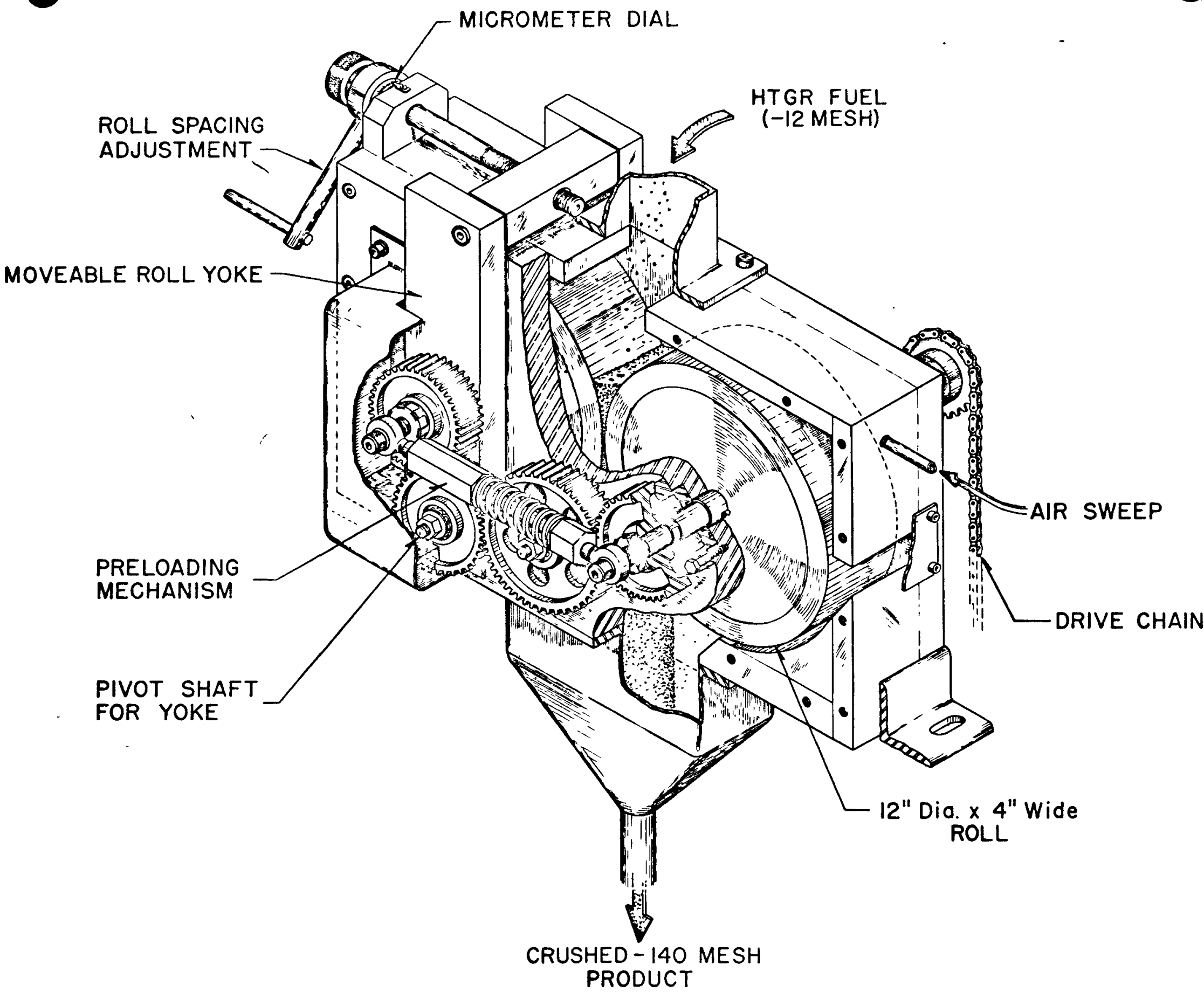


can be maintained between the ends of the rolls and the side plates to minimize bypassing. A heavy coil spring bearing against the moveable roll yoke acts in a direction to force the rolls away from each other; this preloads the spacing adjustment mechanism and helps ensure that there is the least possible change in roll spacing in going from zero throughput to maximum throughput. Preliminary results indicate the machine will grind $-4-$ mesh graphite to -12 mesh at a rate of $120 \mathrm{~kg} / \mathrm{hr}$; the final pass to produce -140 -mesh material can be done at a rate of about $22 \mathrm{~kg} / \mathrm{hr}$.

\subsection{Laboratory-Scale Leaching Studies}

An investigation aimed at determining optimum conditions for leaching crushed carbide-containing graphite fuels has been initiated in the laboratory. The results obtained thus far showed that the highest uranium and thorium recoveries were achieved with boiling 13 to $16 \mathrm{MHNO}_{3}$. Fluoride was not required in the leachant as a dissolution catalyst for the carbide particles but would be required if the particles contained $\mathrm{ThO}_{2}$.

The leaching studies were conducted with unirradiated prototype Peach Bottom fuel that contained about $3 \%$ uranium and $14 \%$ thorium as carbon-coated $\mathrm{ThC}_{2}-\mathrm{UC}_{2}$ particles dispersed in a graphite matrix. The fuel was roll-crushed to -140 mesh, and small samples were leached with sufficient reagent to produce solutions $0.2 M$ in $U+T h$ if all the uranium and thorium were dissolved. After leaching, the residues were washed thoroughly to ensure maximum recovery of solubilized uranium and thorium. In addition to determining the amounts of uranium and thorium leached, the leachate and wash solutions were analyzed for carbon, present in these solutions as soluble 
organic compounds. The amount of carbon found in solution was compared with that originally present in the fuel, assuming that the carbon content $(9.3 \%)$ of the $\mathrm{ThC}_{2}-\mathrm{UC}_{2}$ particles represented combined carbon (carbide).

In 5-hr leaches with boiling nitric acid solutions followed by water-washing of the residues, uranium recoveries increased from about 99.6 to $99.8 \%$ as the nitric acid concentration increased from about 2 to $13 \mathrm{M}$; the corresponding increase in thorium recovery was from about 98 to $99.2 \%$ (Table 2). A similar behavior was noted with nitric acid solutions that were $0.05 \mathrm{M}$ in HF. Uranium and thorium recoveries were not significantly increased by the addition of HF to the leachant. Slight, but possibly significant, increases in recoveries were obtained when the residues were washed with $10 \mathrm{MHNO} 3$ instead of water. These results, however, may merely show that the $5-\mathrm{hr}$ leaching period is insufficient for maximum recovery of uranium and thorium. This hypothesis was fortified by other experiments in which the fuel was leached with two successive batches of fresh, boiling, $13 \mathrm{MHNO}_{3}$. In these experiments, recovery of about $99.9 \%$ of both uranium and thorium was achieved.

The final solutions always contained soluble organic compounds, the products of the reaction of the $\mathrm{ThC}_{2}-\mathrm{UC}_{2}$ with nitric acid. The amount of carbon found in solution corresponded to 13 to $50 \%$ of the carbide carbon. The effect of the soluble organic compounds on feed-preparation procedures and on solvent extraction is being investigated. Preliminary results indicate that foaming is encountered in the Thorex feed adjustment operation. $^{13}$ Earlier work with uranium carbides indicates that the organic material may cause emulsion formation and increased settling times during solvent extraction. ${ }^{14}$ 
Table 2. Uranium and Thorium Recoveries After Leaching of Roll-Crushed Peach Bottom Fuel

Fuel crushed to -140 mesh. Boiling leachant used in each case. Leaching time $=5 \mathrm{hr}$

\begin{tabular}{|c|c|c|c|c|c|}
\hline \multicolumn{2}{|c|}{$\begin{array}{l}\text { Leachant } \\
\text { Composition } \\
(M)\end{array}$} & \multirow{2}{*}{ Wash } & \multicolumn{2}{|c|}{ Recoveries (\%) } & \multirow{2}{*}{$\begin{array}{l}\text { Carbide Carbon } \\
\text { in Leachate } \\
\text { (\% of original) }\end{array}$} \\
\hline $\mathrm{HNO}_{3}$ & $\mathrm{HF}$ & & & & \\
\hline 2.0 & 0 & Water & 99.6 & 98.2 & 24 \\
\hline 5.0 & 0 & Water & 99.7 & 99.1 & 31 \\
\hline 13.0 & 0 & Water & 99.8 & 99.2 & 13 \\
\hline 15.8 & 0 & Water & 99.8 & 98.8 & -- \\
\hline 2.0 & 0.05 & Water & 99.8 & 96.9 & 50 \\
\hline 5.0 & 0.05 & Water & 99.8 & 99.0 & 32 \\
\hline 13.0 & 0.05 & Water & 99.8 & 99.4 & -- \\
\hline 13.0 & 0.05 & Water & 99.7 & 99.5 & 22 \\
\hline 13.0 & 0.05 & $10 \mathrm{MHNO}_{3}$ & 99.9 & 99.9 & -- \\
\hline 13.0 & 0.05 & $10 \mathrm{M} \mathrm{HNO}_{3}$ & 99.8 & 99.9 & 52 \\
\hline
\end{tabular}


This was minimized by permanganate oxidation to destroy the organics. Investigations are under way to see if the Thorex feed preparation boildown will eliminate the objectionable organic material or if additional treatment will be required.

\subsection{Engineering-Scale Leaching Studies}

Preliminary experiments confirmed that fine grinding of Peach Bottom fuel to -140 mesh was necessary to rupture of all fuel particle coatings. Also, continuous, controlled addition of fuel to the acid in the leacher was found desirable to minimize foaming. After this, leaching equipment was built to process as much as $5 \mathrm{~kg}$ of ground fuel per batch as a slurry in 10 liters of leachant. The leacher was a heated 4-in.-diam vessel provided with an air-lift sparger and an external slurry recirculation line to provide good mixing. Crushed fuel was fed at a controlled rate to the leacher by a pneumatic transport system. The filter was a 6-in.-diam vessel with a granularalumina-perforated-metal-plate filter cake support.

The flowsheet conditions and leaching results are summarized in Fig. 7 for the first experiment. The leaching acid contained fluoride; however, as noted in the laboratory studies, it was probably unnecessary. In the experiment, the rate of addition of ground fuel to the leacher was limited to about $75 \mathrm{~g} / \mathrm{min}$ by the generation of foam from the initial reaction with the boiling acid. During the 7-hr reaction period, the ground fuel was kept suspended in the leacher by boiling and by the sparger. The slurry was then transferred by vacuum to the filter vessel, where the graphite residue was separated from the leach liquor and water washes by vacuum filtration. Solution samples taken during leaching showed that the concentration of dissolved carbon reached 
ORNL DWG 66-160

PEACH BOTTOM FUEL COMPACTS

$15 \%$ Th, $3.5 \% U$, Balance $C$.

Roll Crushed to -140 Mesh

$3620 \mathrm{gm}$

$75 \mathrm{gms} / \mathrm{min}$

(Pneumatic Transport)

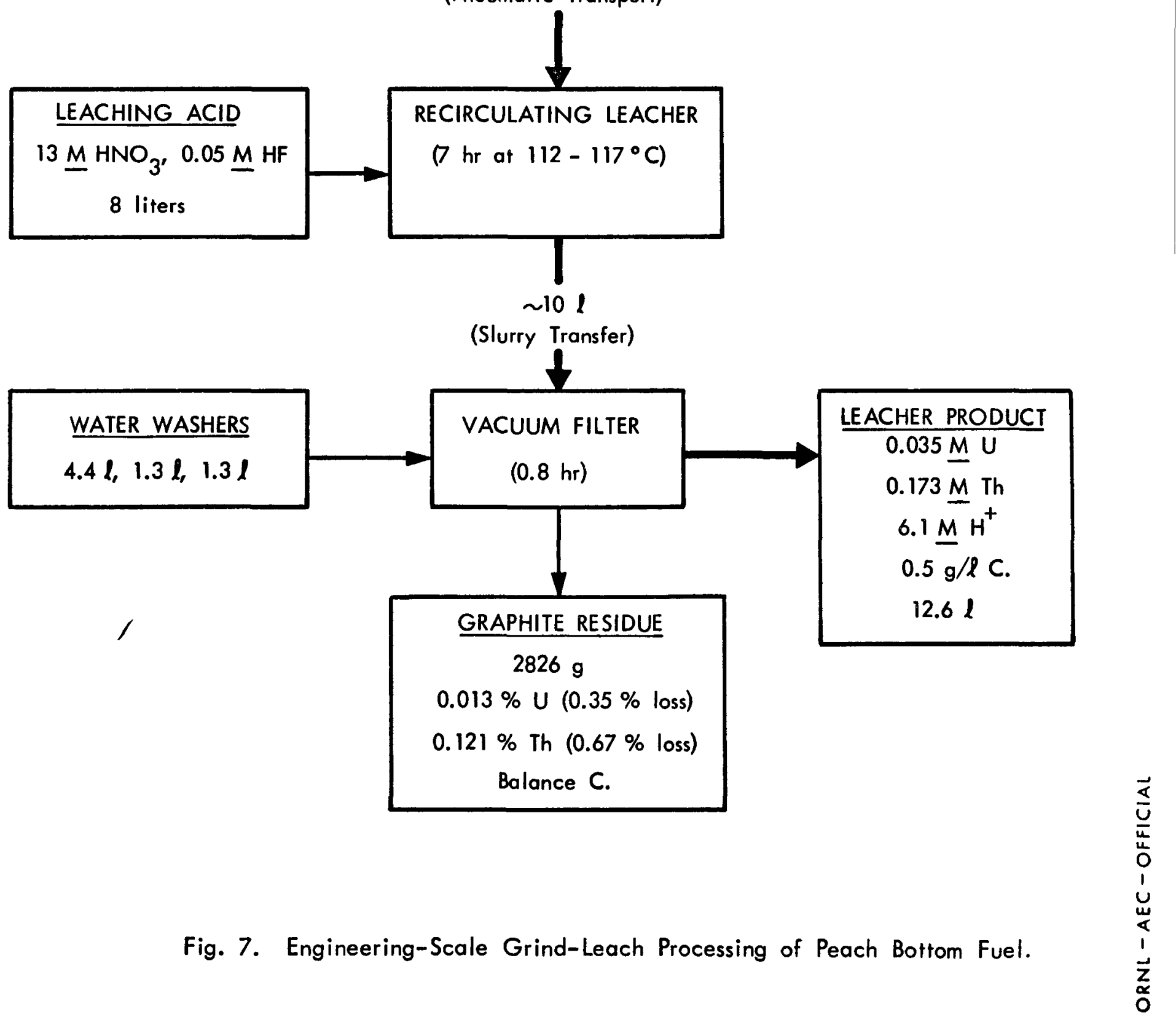


c. pecik value of cibout $3.5 \mathrm{~g} / \mathrm{liter}$ in $1.5 \mathrm{hr}$ (cpproximately $0.75 \mathrm{hr}$ after cdding c.! we graphite to the leacher) and slowly decreased to $i .15 \mathrm{~g} /$ liter at the end of the 7-hr leaching period.

The resulis of the first run inciticated what $99.65 \%$ of the virnium and $99.33 \%$ o: .he inorium was recovered from the full, in good agreement witin its results of abcictory work. Addiriona! washinis oi a portion of ine residue with hot $0.1 \mathrm{MHNO}_{3}$ showed that losses could be reduced sightly at the cost of approximately doubling the

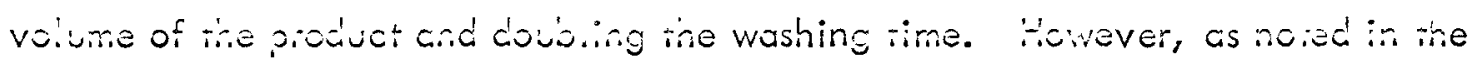
aschatory lecching experiments, washing with concentraiea coid may be more effective $\therefore$ recusing the losses to a very low leva!. The coich wast coudd then be used as the anchant for the next 'ausch. Additional experimentation is under way.

\subsection{Fitration of Grap'itite Siviries}

Mecisuienents of the permeability to $0.1 \mathrm{MHO}_{3}$ of 1-to-2.5-i-deep bed's ci ine $-140-$ rinu residue from the experiment describec in Sect. 3.3 were correlated by the equation $V=0.9(A P / L)(I / \mu)$, where $V$ is the flow rate through the bed in cai : $\mathrm{A}^{-1} \mathrm{fr}^{-2} ;(\Delta \mathrm{O} / \mathrm{L})$ is rhe pressure diop hrough the bed in psi per ft of bed; and $\mu$, ne solution viscosity, is in centipoises (Fig. 8). The bed depth L can be calculated Ly cossumirg that rie density of the grajitite setried uncer $0.1 M$ HNOj is cibout $0.00 \mathrm{~g} / \mathrm{cm}^{3}$, cn average value derermined in previous experiments. These results inciccie that vacuum filtration will be satisfactory if ine fit'ter cake is not very deep. On ...e othe: hand, if other consiciections such cs criticcity requirements dicicte a

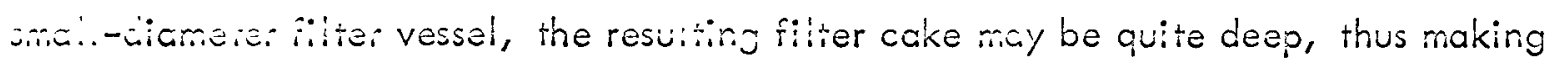
jessure filichion more attractive than vacuum filtration. 


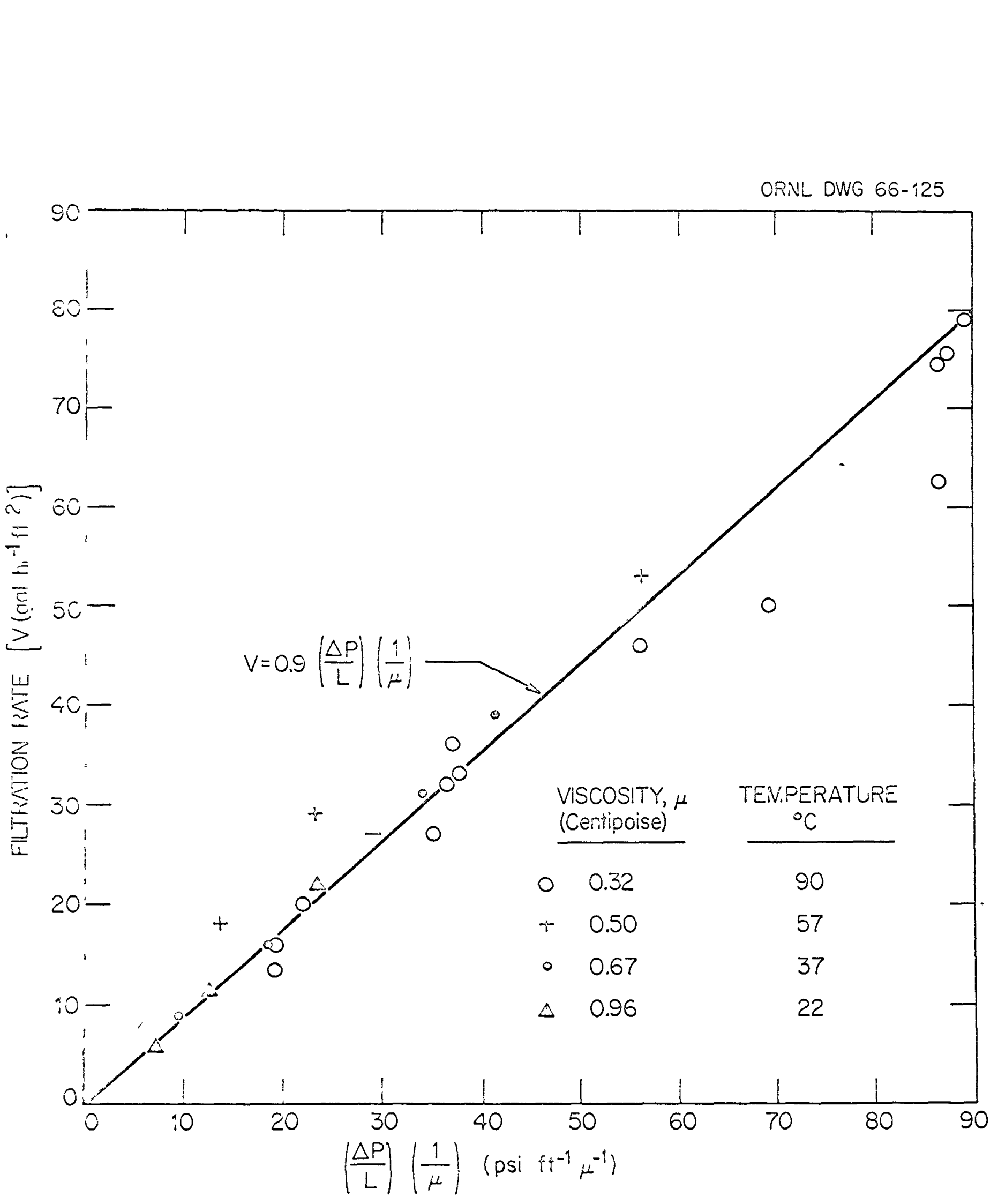

Fig. 8. Permeability of Filter Cukes of - $\$ 40$ Mesh Leached Graphire to $0.1 \mathrm{M}$ Nitric Acid. 


\section{BURN-LEAC:- PROCESS DEVELOPMENT FOR GRAPHI:E-3ASE HTGR FUELS}

The burn-leach process (Fig. 9) for graphite-bcse HiGR fuel consists in crushing the fuel to a suitable size and feeding it to a fuidized-bed burner where the graphite and carbide carbon are converted to $\mathrm{CO}_{2}$ ani $\mathrm{CO}$ zases. The resulting fuel oxides are then dissolved in fluoride-catalyzed nitric acid and, citer feed adjustment, uranium and tho:ium are recovered by solvent extraction. The fluicized-bed burner permits high combustion rates at relatively low temperatures, produces a free-flowing ash, and is easily operated.

Engineering feasibility of the burn-leach process was established in small-scale exieriments with unirradiated fuel. ${ }^{15}$ The principal process problem is whether the inmer off-gas can be decontaminated sufficiently to permit its release to the atmosphere. Hici-cell tests are currently under way at ORNL to demonstrate the process. The principal objective of these experiments is to determine the extent of volatilization of fission products into the off-gas and to test various methods for off-gas cleanup. Suppiemental objectives are to determine the amount of fission product deposited on the burner surfaces and to study leaching, feed preparation, and solvent extraction performance.

As a guide to these experiments, the fission product activity of the burner off-gas was estimated ${ }^{16}$ for a plant processing HTGR fuel with a C/Th ratio of 200 and a $235 \mathrm{U} / 232$ Th ratio of 0.068 . The calculations were made for a burnup of 84,000 Mwd/ton, with 2100 days irradiation and 250 days of cooling. The fission products $\mathrm{Kr}, \mathrm{Ru}, \mathrm{Te}, \mathrm{Cs}, \mathrm{Se}$, and $\mathrm{Tc}$ were found to be the only ones that would volatilize significantly as oxides during combustion. Since the composition of the burner off-gas 
TUEL RECLIVING

AND STORAGE

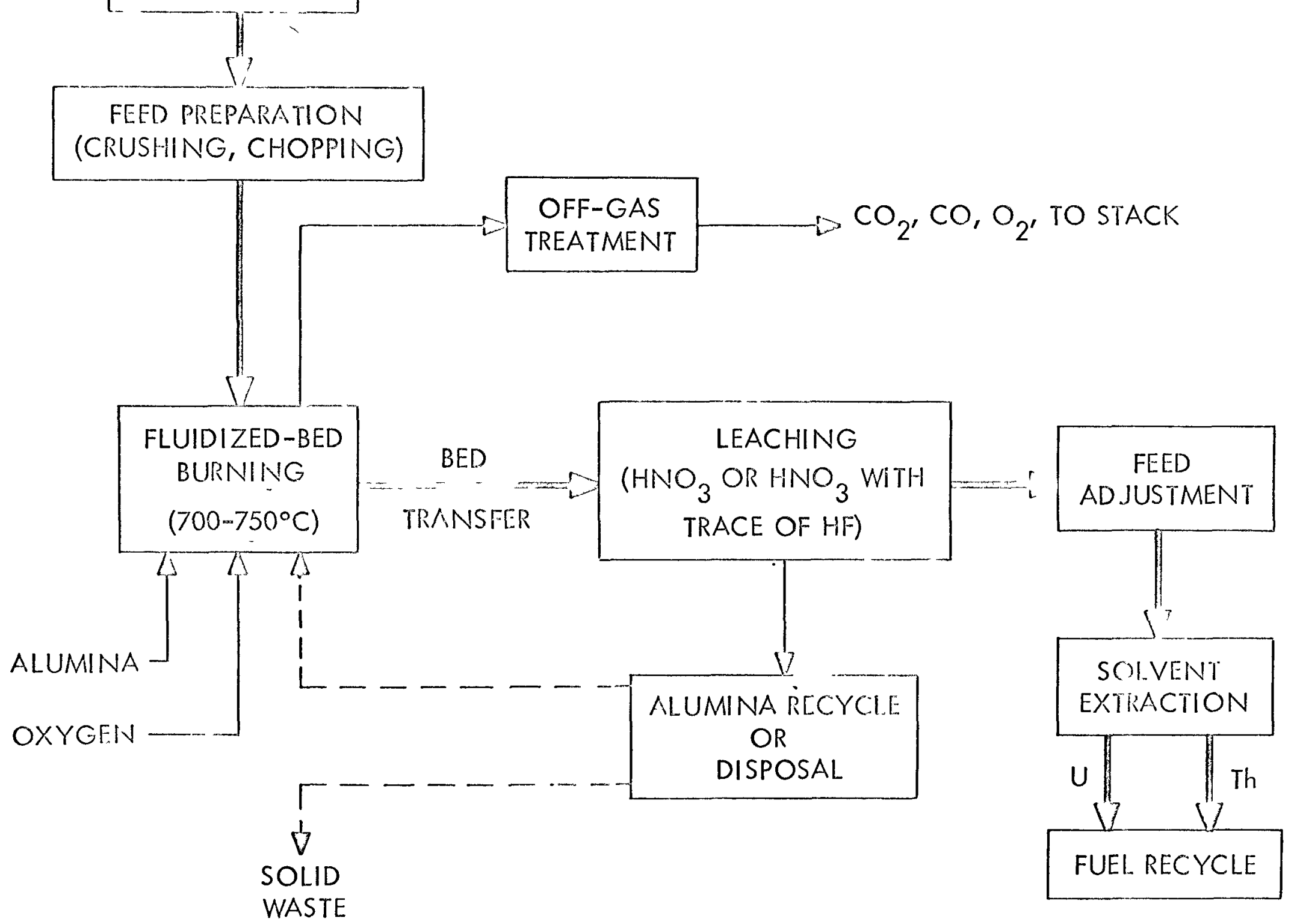

Fig. 9. Burn-Leach Process for Graphite-Base Reactor Fuels. 
déerermined experimentally ${ }^{15}\left(5 \% \mathrm{CO}, 5 \% \mathrm{O}_{2}\right.$, and $\left.90 \% \mathrm{CO}_{2}\right)$ is a nonequilibrium mixture, one cannot predict whether oxidation or reduction (by $\mathrm{CO}$ ) of the fission products will have the predominating influence. Oxidizing conditions were assumed, since fission product volatilization is most likely to occur under this condition; and, hence, the fission product volatilization results predicted by calculation would tend to be conservative compared to those obtained in actual fluidized-bed combustion. The results of the calculations (Fig. 10 ) roughly substantiate tube furnace combustion experiments and indicate that appreciable volatilization of fission product oxides may occur at $750^{\circ} \mathrm{C}$. If the off-gas is cooled to room temperature and passed through absolute filters before discharge, then ${ }^{85} \mathrm{Kr}$ will be the principal activity in the gas and with not normally represent an atmospheric disposal problem. Another tentative conclusion is that the fission products noted above may tend to reflux between the hot fluicized bed and the burner filiers, thus creating a heating problem in the bumer if allowed to accumulate indefinitely. Resolution of these problems must await the results of the hot-cell experiments; so it is premature to draw final conclusions from the preceding doita.

\section{ADSORPTION OF PROTACTINIUM ON UNFIRED VYCOR}

Adsorption of protactinium on unfired $V y$ cor has the capability of producing low${ }^{232} U$-content $233 \cup$ from highly irradiated power reactor fuels. The process for recovering $233 \mathrm{~Pa}$ by adsorption on unfired $V_{y}$ cor glass ${ }^{17}$ was demonstrated in hot-cell experimeriis with feeds prepared by dissolving sol-gel thoria fuel specimens in boiling $13 \mathrm{MHNO}_{3}-0.05 \mathrm{MHF}-0.1 \mathrm{MAl}\left(\mathrm{NO}_{3}\right)_{3}$. The specimens had been irradiated 


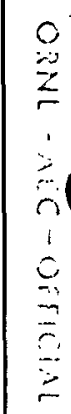

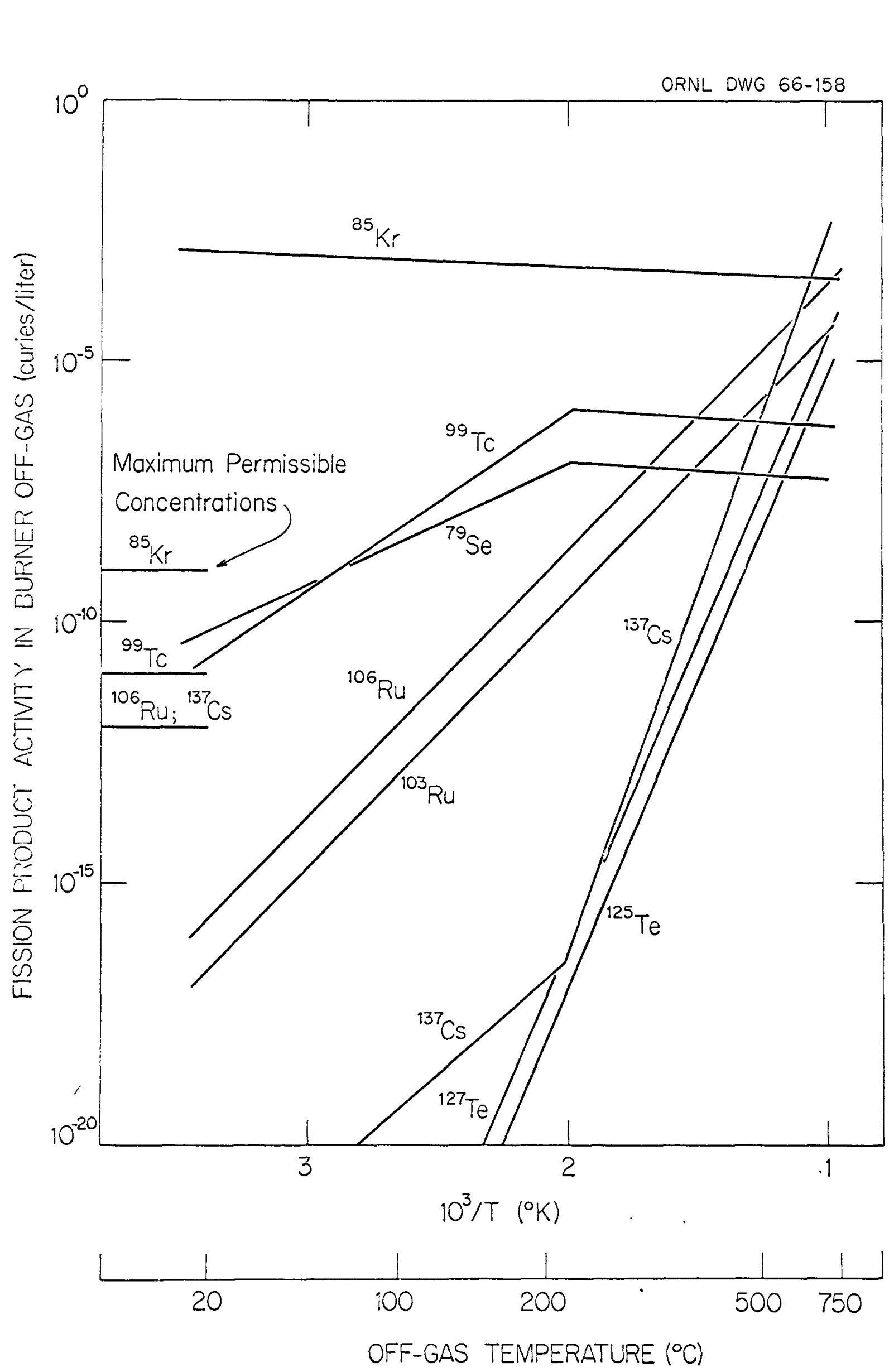

Fig. 10. Calculated Equilibrium Fission Product Content of Fluid Bed Burner Off-Gas (Oxygen pressure $=1 \mathrm{~atm}$ ). 
to about $5000 \mathrm{Mwd} /$ metric ton in an average unperturbed neutron flux of $2.6 \times 10^{14}$ and decayed 27 days.

As an example of the results obtained in the hot-cell runs, Fig. 11 shows the data obtained in an experiment with 100- to 120-mesh unfirea Vycor. About $97 \%$ of the protactinium was adsorbed from a solution containing $126 \mathrm{mg}$ Th per $\mathrm{ml}$, $0.82 \mathrm{mg} \cup$ per ml, $54 \mathrm{mg}{ }^{233} \mathrm{~Pa}$ per liter, and $1.4 \times 10^{12}$ gamma counts $\mathrm{min}^{-1} \mathrm{ml}^{-1}$. The solution was $11.4 \mathrm{M}$ in $\mathrm{HNO}_{3}, 0.05 \mathrm{M}$ in $\mathrm{HF}, 0.1 \mathrm{M}$ in $\mathrm{Al}\left(\mathrm{NO}_{3}\right)_{3}$ and was passed through a column $0.9 \mathrm{~cm}$ in diameter and $17 \mathrm{~cm}$ long containing $7 \mathrm{~g}$ of unfired Vycor. At a flow rate of about $1 \mathrm{ml} / \mathrm{min}$, the column was loaded to $3.1 \mathrm{mg}$ of $233 \mathrm{~Pa}$ per gram of glass. The loaded column had to be cooled with water to prevent boiling. The Vycor was washed with about eight column volumes of $10 \mathrm{MNO}_{3}-0.1 \mathrm{M} \mathrm{Al}\left(\mathrm{NO}_{3}\right)_{3}$ at a flow rate of $0.5 \mathrm{ml} / \mathrm{min}$. This removed $1.5 \%$ of the adsorbed protactinium. The remainder of the protactinium was then eluted with $0.5 \mathrm{M}$ oxalic acid. The first $15 \mathrm{ml}$ of product contained about $96 \%$ of the protactinium at an average concentration of $1.46 \mathrm{mg} / \mathrm{ml}$ or about 25 times the concentration of protactinium in the feed. The eluant sample having the peak $233 \mathrm{~Pa}$ concentration $(2.86 \mathrm{mg} / \mathrm{ml})$ had to be diluted to prevent boiling. The protactinium product was decontaminated for zirconium-niobium, rare earths, thorium, and uranium by factors of $5.5,4.8 \times 10^{3}, \geq 1 \times 10^{4}$, and $\geq 5.7 \times 10^{2}$, respectively. The ${ }^{233} U$ which would be obtained from the decay of the protactinium would contain only about 0.1 ro $0.5 \mathrm{ppm}$ of ${ }^{232} \mathrm{U}$.

Radiation appeared to have little or no effect on the unfired Vycor glass. A second experiment, using this same column, showed very nearly the same adsorption and stripping characteristics. 


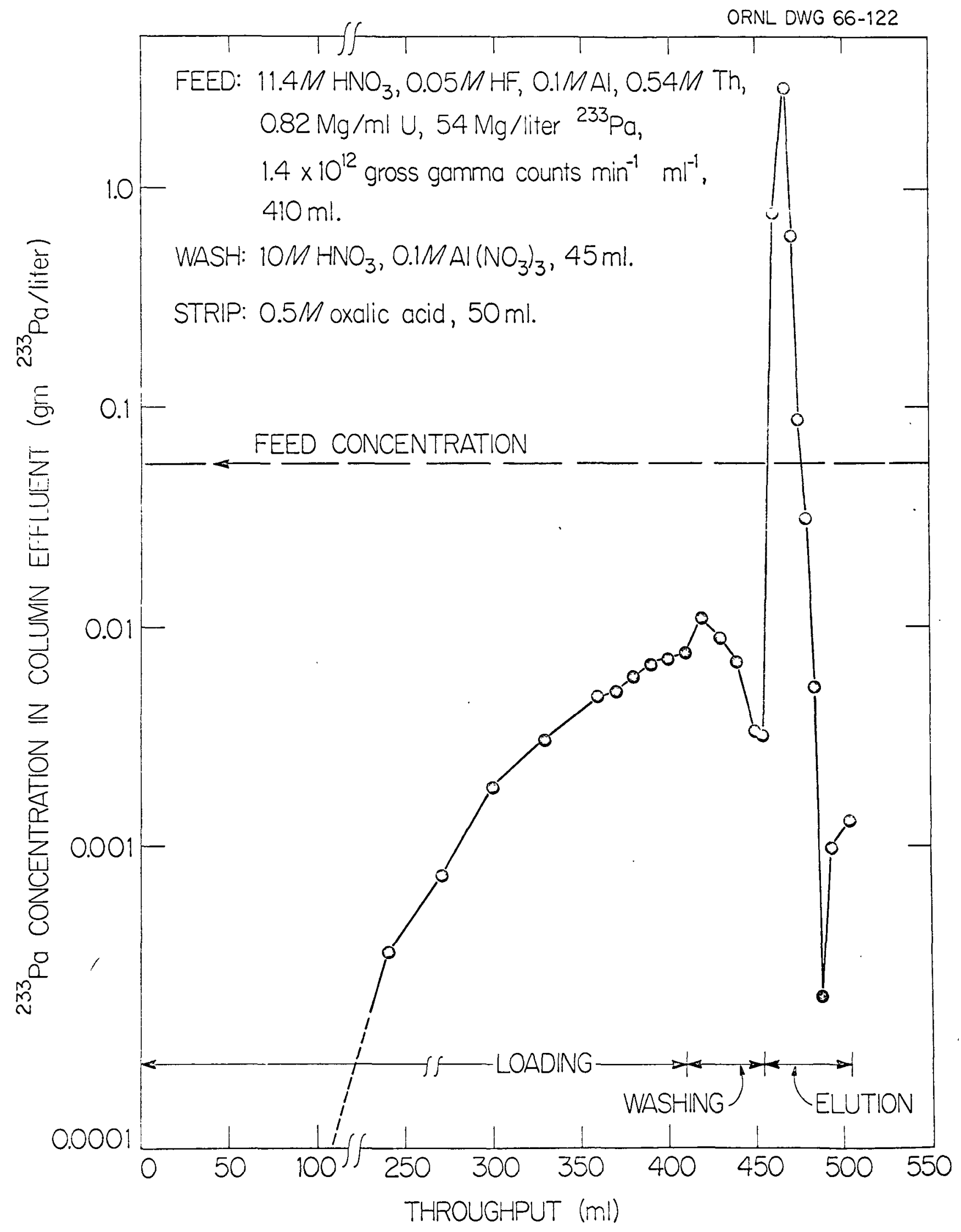

Fig. 11. Isolation of ${ }^{233}$ Pa by Sorption on 100-120 Mesh Uníired Vycor Glass. 
In a more optimized process for recovering protactinium, the $V y c o r$ would probably be loaded to about $2.5 \mathrm{mg}$ of $233 \mathrm{~Pa}$ per gram of glass to ensure $99 \%$ adsorption of the protactinium. This would result in slightly lower losses in the wash step and perhaps lower protactinium concentrations in the product but would have no effect on the product purity.

Other experiments showed that silica gel was slightly less effective and zirconium phosphate was only half as effective for protactinium recovery. Suitable stripping methods were not found for zirconium phosphate.

\section{CLOSE-COUPLED PROCESS STUDIES}

The gamma activity associated with daughers of both ${ }^{233} U$ and ${ }^{239} \mathrm{Pu}$ recycled from power reactors necessitates shielding for fuel fabrication. Since this shielding is required, only a partial decontamination from fission products may be necessary during chemical processing. Fuel cycle cost reduction may also be achieved if processing and fabrication plants are close-coupled and perhaps located at the reactor station. The purpose of this program is to study simplified, low-cost, chemical processing metnods that will yield a product decontaminated from fission products by a factor of about 1000 and that will be suitable as a feed for the sol-gel process for remote fuel refráorication. Initial emphasis is on the thorium fuel cycle; later we will consider the problems of liquid-metal-cooled fast-breeder reactors. The best application of close-coupled processing in the immediate future may be for the HTGR's; however, for initial evaluarion of the principle of close-coupled processing, we are considering a conventional Zircaloy-clad $\mathrm{ThO}_{2}-\mathrm{UO}_{2}$ fuel for which processing technology is we!l developed. 


\subsection{Chemical and Equipment Development}

The chemical development program initially consisted of evaluating processing methods other than solvent extraction to see if any would be more suitable for a closecoupled plant. $^{18}$ A number of possible methods such as peroxide, oxalate, and phosphate precipitation, and electrodialysis, were investigated; however, anion exchange was the only method that gave promise of being developed in to a workable process. However, resin capacity and decontamination were low, thus creating a recycle problem and requiring several cycles of anion exchange. It was concluded that solvent extraction is still the best choice for uranium and thorium recovery in a close-coupled plant such as the Thorium-Uranium Recycle Facility.

We then investigated a batch differential solvent extraction system to see if it was more suitable than continuous solvent extraction for a small plant. With $30 \%$ TBP

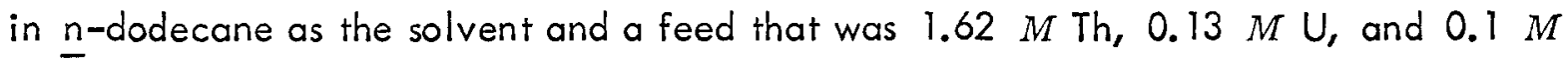
acid deficient, more than $99.9 \%$ of the uranium and $48 \%$ of the thorium were extracted in 3.3 volumes of solvent. The decontamination factor of the uranium from gross gamma activity was 1400. Continuing the extraction until 9.8 volumes of solvent were used resulted in the extraction of $95 \%$ of the thorium and lowering the overall decontamination factor to 100 . The remaining $5 \%$ of the thorium would have to be recycled to avoid lowering the overall decontamination factor below 100. Further testing showed that about $25 \%$ of the fluoride and about $40 \%$ of the zirconium dissolved in the leaching was extracted. The fluoride, in particular, would be highly undesirable in the reconstituted fuel. A high-thorium-content, dense, second organic phase will form in TBP extraction of thorium if the solubility of the TBP-thorium complex is exceeded. This 
second phase was encountered in laboratory experiments but caused no difficulty. However, batch extraction tests in a small pulsed column were unsuccessful because an aqueous-second-organic-phase emulsion formed and the organic holdup in the column was excessive, even at very low throughput rates. For these and other reasons, we concluded that batch extraction for uranium and thorium recovery was undesirable. We are now concentrating on improving the continuous Thorex solvent extraction process.

\subsection{Conceptual Plant Studies}

A.conceptual engineering design and preliminary economic evaluation was made for a small close-coupled plant for processing, at a rate of $165 \mathrm{~kg} /$ day, Zircaloy-clad, vibratorily-packed sol-gel (U-Th) $\mathrm{O}_{2}$ fuel irradiated to at least $20,000 \mathrm{Mwd} / \mathrm{metric}$ ton. This particular capacity and fuel type (metal-clad oxide) was chosen to permit comparison of the close-coupled plant with a small on-site plant of similar capacity but for low-enrichment uranium fuel, very good decontamination of the products, and conventional direct fabrication. The ground rules and cost assumptions used in the close-coupled study were practically the same as those used in the small-plant study. In our study, it was assumed that batch-differential solvent extraction was used in the processing plant; when this proved impractical, the study was repeated to estimate costs for a single-extraction-cycle continuous-extraction system. We found that the difference in costs between the batch and the continuous processes was insignificant. The close-coupled plant was assumed to be fully integrated with a 1000-Mw (electrical) reactor station and included (1) underwater fuel element storage and dismantling; 
(2) a remote maintenance shear-leach head-end, with feed adjustment, acid recovery, high-level off-gas treatment, and high-and low-level waste evaporation equipment in the same area; (3) solvent extraction with 30\% TBP followed by sol preparation according to simplified method based on extraction, with a long-chain amine, of the nitrate from blended uranium and thorium nitrate product solutions; (4) gel formation, firing, sizing; and (5) fuel fabrication in an adjoining remotely operated facility similar in design to TURF. ${ }^{19}$ Capital costs for the processing plant were estimated ${ }^{20}$ from preliminary conceptual equipment and building layouts; operating costs were derived by adjusting published data ${ }^{21}$ to an integrated facility of relatively small size and adding perpetual care waste storage charges derived from computer calculations. 22 Capital costs for the fabrication plant were estimated by computer ${ }^{23}$ and operating costs for the fabrication plant were estimated on roughly the same basis as for the chemical plant. Fully developed technology was assumed and a frugal approach was used on plant staffing and overhead.

The processing and remote fabrication cost (Table 3) of $\$ 156 / \mathrm{kg}(U+T h)$ cannot be compared with today's costs because experience is not available for remote fabrication. However, the processing cost component is estimated to be about $\$ 75 / \mathrm{kg}(\mathrm{U}+\mathrm{Th})$ compared to the published NFS price ${ }^{21}$ of about $\$ 78 / \mathrm{kg}(U+T h)$ for processing the Indian Point Reactor $\mathrm{ThO}_{2}$ core. This comparison is encouraging, considering that the close-coupled plant throughput is one-third of the NFS rating for thorium and the processing product is a denitrated, mixed U-Th sol suitable for gel formation. However, the thorium fuel cycle still costs more than low-enrichment uranium. For example, the small on-sitis plant study ${ }^{24}$ estimated a cost of $\$ 120 / \mathrm{kg}$ of low-enrichment uranium. 
Table 3. Capital and Operating Costs for a Small Close-Coupled Processing Plant

Capital Cost

Processing building and equipment

$\$ 7,430,000$

Fabrication building and equipment

$5,300,000$

Startup cost, processing planta

Startup cost, fabrication planta

$1,420,000$

$1,448,000$

Total capital investment

$\$ 15,598,000$

Annual Operating Cost $^{b}$

Capital amortization at $22-i / 2 \%$ per year

Processing plant (direct costs)

$\$ 3,510,000$

Fabrication plant (direct costs)

$1,420,000$

$2,556,000$

Solid waste

75,000

High-level waste storage

282,000

Medium-level waste storage

153,000

Total annual operating cost

$\$ 7,996,000$

$\$ 156 / \mathrm{kg}(U+T h)$

a One year's operating cost, excluding waste storage and fuel element hardware.

b Exclusive of inventory charges and cost for $U+$ Th makeup. 
This indicates that the more complex thorium processing system and remote fabrication for metal-clad oxide fuel costs about $30 \%$ more than low-enrichment uranium oxide fuel using high-decontamination processing and direct fabrication. Thus, it appears that the future of the thorium cycle lies with the advanced converters, such as the HTGR, where the unique advantages of thorium as a fuel can be realized. Extra head-end costs, perhaps amounting to as much as $\$ 134 / \mathrm{kg}(U+T h)$ in the case of HTGR fuels, ${ }^{15}$ may be charged for processing in existing plants. Therefore, we think that small close-coupled plants may be a desirable interim solution to minimize cost disadvantages of thorium fuel until large central thorium fuel cycle plants can be justified. 


\section{REFERENCES}

1. R. H. Rainey and J. G. Moore, Laboratory Development of the Acid-Thorex Process for Recovery of Consolidated Edison Thorium Reactor Fuel, ORNL-3155 (April 27, 1962).

2. C. D. Watson, B. C. Finney, G. A. West, and B. A. Hannaford, The Shear-Leach Process for Spent Nuclear Fuels, ORNL-3625 (in preparation).

3. R. E. Blanco, L. M. Ferris, C. D. Watson, and R. H. Rainey, "Aqueous Processing of Thorium Fuels," Proceedings of the Thorium Fuel Cycle Symposium at Gatlinburg, Tennessee, December 5-7, 1962, TID-7650, Book 1, pp 384-435.

4. J. B. Adams, A. M. Benis, and C. D. Watson, Comparative Cost Study of Processing Stainless-Steel-Jacketed $\mathrm{UO}_{2}$ Fuel: Mechanical Shear-Leach vs SulfexCore Dissolution, ORNL-3227 (April 6, 1962).

5. J. T. Roberts, L. M. Ferris, E. L. Nicholson, R. H. Rainey, and C. D. Watson, Reprocessing Methods and Costs for Selected Thorium-Bearing Reactor Fuel Types, ORNL-TM-1139 (May 14, 1965).

6. J. H. Goode and J. R. Flanary, Dissolution of Irradiated Stainless-Steel-Clad $\mathrm{ThO}_{2}-\mathrm{UO}_{2}$ in Fluoride-Catalyzed Nitric Acid Solutions: Hot-Cell Studies on Pelletized, Arc-Fused, and Sol-Gel-Derived Oxides, ORNL-3725 (Jan. 1965).

7. L. M. Ferris and C. D. Watson, ORNL, unpublished work (Nov.-Dec. 1964).

8. J. H. Goode, "The Release of Tritium and Krypton-85 During Processing of $\mathrm{ThO}_{2}-\mathrm{UO}_{2}$ Reactor Fuel," to be presented at the ANS National Meeting, Denver, Colorado, June 20-23, 1966. 
9. W. J. Ross, J. E. Strain, and J. W. Landry, "Monitoring of Leached Fuel Elements with a Neutron Generator," to be presented at the ANS National Meeting, Denver, Colorado, June 20-23, 1966.

10. M. E. Whatley et al., Unit Operations Section Quarterly Progress Report AprilJune 1965, ORNL-3868 (Dec. 1965).

11. H. O. Witte and L. M. Ferris, Ball-Milling of Graphite-Base Reactor Fuel, ORNL-TM-1412 (Feb. 3, 1966).

12. R. H. Perry, C. H. Chilton, and S. D. Kirkpatrick, Chemical Engineers' Handbook, 4th ed., pp 8-17, McGraw-Hill, New York, 1963.

13. R. H. Rainey, personal communication.

14. J. R. Flanary et al., Hot-Cell Studies of Aqueous Dissolution for Processes for Irradiated Carbide Reactor Fuels, ORNL-3660 (Sept. 1964).

15. E. L. Nicholson, L. M. Ferris, and J. T. Roberts, Burn-Leach Processes for GraphiteBase Reactor Fuels Containing Carbon-Coated Carbide or Oxide Particles, ORNL-TM-1096 (April 2, 1965).

16. H. O. Witte, Calculation of the Fission Product Activity in the Off-Gases from a Burn-Leach Process for Graphite-Base Fuels, ORNL-TM- (in press).

17. J. H. Goode and J. G. Moore, Adsorption of Protactinium on Unfired Vycor: Final Hot-Cell Experiments, ORNL-3950 (in preparation).

18. L. M. Ferris, Experimental Survey of Close-Coupled Processing Methods for Fuels Containing Uranium and Thorium, ORNL-3952 (in preparation). 
19. A. L. Lotts and D. A. Douglas, Jr., Refabrication Technology for the ThoriumUranium-233 Fuel Cycle, ORNL-TM-1141 (June 2, 1965).

20. W. G. Stockdale, personal communication.

21. "Chemical Processing Plant," Hearing Before the Joint Committee on Atomic Energy, Congress of the United States, May 14, 1963, U.S. Government Printing Office, Washington, D. C., 1964.

22. Royes Salmon, ORNL, personal communication.

23. T. N. Washburn, ORNL, personal communication.

24. W. E. Unger, F. E. Harrington, J. R. May, S. F. Scott, and T. N. Washburn, On-Site Fuel Processing and Recycle Plant Design Study, ORNL-3959 (in press). 